\title{
Socioeconomic, demographic and obstetric profile of pregnant women with Hypertensive Syndrome in a public maternity
}

\author{
Perfil socioeconômico, demográfico e obstétrico de gestantes com \\ Síndrome Hipertensiva de uma maternidade pública \\ Perfil socioeconómico, demográfico y obstétrico de mujeres embarazadas \\ con Síndrome Hipertensiva en un hospital de maternidad pública
}

\section{Lia Maristela da Silva Jacoba Artur Paiva Santos ${ }^{b}$ \\ Maria Helena Baena de Moraes Lopes ${ }^{a}$ Antonieta Keiko Kakuda Shimo ${ }^{a}$}

\section{How to cite this article:} Jacob LMS, Santos AP, Lopes MHBM, Shimo AKK. Socioeconomic, demographic and obstetric profile of pregnant women with Hypertensive Syndrome in a public maternity. Rev Gaúcha Enferm. 2020;41:e20190180. doi: https://doi. org/10.1590/1983-1447.2020.20190180

\footnotetext{
- Universidade Estadual de Campinas (UNICAMP), Faculdade de Enfermagem. Campinas, São Paulo, Brasil.

b Universidade Federal do Ceará (UFC), Faculdade de Medicina, Departamento de Saúde Comunitária. Fortaleza, Ceará, Brasil.
}

\begin{abstract}
Objective: To describe the socioeconomic, demographic and obstetric profile of pregnant women with Gestational Hypertensive Syndrome.

Methods: A descriptive and correlational study, conducted in Maternity School Assis Chateaubriand, with 120 pregnant women, through a questionnaire analyzed by descriptive and analytical statistics.

Results: most women had chronic hypertension (60.83\%). Regarding the socioeconomic and demographic profile, most pregnant women had a mean age of $30.9 \pm 6.9$ years, were Catholic, brown skin color, employed, in stable unions, complete high school education, and income of up to R\$954.00. Regarding the obstetric profile, their Body Mass Index was up to 66, slightly elevated blood pressure, an average of five prenatal consultations, two pregnancies, one delivery and no abortions. Women with chronic hypertension were older $(p=0.0024)$, had lower gestational age $(p=0.0219)$ and a higher number of abortions $(p=0.0140)$.

Conclusions: Pregnant women are overweight/obese, with a mean age of 30.9 years and are socially vulnerable. Pregnant women with chronic hypertension are older and have a higher number of abortions.
\end{abstract}

Keywords: Nursing. Epidemiology. Women's health. Hypertension, pregnancy-induced.

\section{RESUMO}

Objetivo: Descrever o perfil socioeconômico, demográfico e obstétrico de gestantes com Síndrome Hipertensiva Gestacional.

Métodos: Estudo descritivo e correlacional, realizado em unidade Maternidade Escola Assis Chateaubriand, com 120 gestantes, mediante questionário analisado por estatística descritiva e analítica.

Resultados: Prevaleceram gestantes com hipertensão crônica (60,83\%). Quanto ao perfil socioeconômico e demográfico, prevaleceram gestantes com idade média de 30,9 \$6,9 anos, católicas, pardas, com vínculo empregatício, união estável, ensino médio completo e renda até R\$ 954,00. Quanto ao perfil obstétrico, eram gestantes com Índice de Massa Corporal até 66, pressão arterial levemente elevada, média de cinco consultas pré-natais, duas gestações, um parto e nenhum aborto. As mulheres com hipertensão crônica eram mais velhas $(p=0,0024)$, tinham menor idade gestacional $(p=0,0219)$ e maior número de abortos $(p=0,0140)$.

Conclusões: as gestantes apresentam sobrepeso/obesidade, idade média de 30,9 anos e vulnerabilidade social. As gestantes com hipertensão arterial crônica, são mais velhas e com maior número de abortos.

Palavras-chave: Enfermagem. Epidemiologia. Saúde da mulher. Hipertensão induzida pela gravidez.

\section{RESUMEN}

Objetivo: Describir el perfil sociodemográfico y obstétrico de embarazadas con Síndrome Hipertensivo Gestacional.

Métodos: Estudio descriptivo y correlacional, hecho en una unidad Escuela de maternidad Assis Chateaubriand, con 120 embarazadas, utilizando un cuestionario analizado por estadísticas descriptivas e inferenciales.

Resultados: Prevalecieron las embarazadas con hipertensión crónica (60,83\%). En cuanto al perfil sociodemográfico, prevalecieron las embarazadas con promedio de edad de 30,9 años, católicas, pardas, con relación laboral, unión estable, nivel de escolarización medio e ingreso de hasta R\$954.00. En cuanto al perfil obstétrico, eran embarazadas con Índice de Masa Corporal de hasta 66, presión arterial ligeramente alta, promedio de cinco consultas prenatales, dos embarazos, un parto y ningún aborto. Las mujeres con hipertensión crónica eran mayores $(p=0,0024)$, tenían edad gestacional menor $(p=0,0219)$ y mayor número de abortos $(p=0,0140)$. Conclusiones: Las mujeres embarazadas presentan una edad media de 30 años, un nivel sociodemográfico bajo y sobrepeso/ obesidad. Las mujeres embarazadas con hipertensión arterial crónica son mayores y tienen un mayor número de abortos. Palabras clave: Enfermería. Epidemiología. Salud de la mujer. Hipertensión inducida en el embarazo. 


\section{口INTRODUCTION}

The association between hypertension and pregnancy is frequent ${ }^{(1)}$. Regarding the epidemiological context, hypertensive disorders during pregnancy affect about $10 \%$ of all pregnant women worldwide ${ }^{(1-2)}$. In developed countries, this incidence varies between 2 and $8 \%$, lower than in developing countries, such as Brazil, which can have rates above $10 \%{ }^{(3)}$.

This group of hypertensive disorders includes preeclampsia and eclampsia, gestational hypertension and chronic hypertension, being an important cause of severe acute morbidities, long-term disabilities and even death of mothers and babies(2).

The diagnosis of hypertension during pregnancy is made when blood pressure levels are 140/90 $\mathrm{mmHg}$ or higher. It can be classified as preeclampsia when hypertension arises after the 20th week of gestation associated with proteinuria; as chronic hypertension, when identified before pregnancy or before the 20th week; and preeclampsia on chronic hypertension, when the patient has previous hypertension and proteinuria after the 20th week of pregnancy ${ }^{(1)}$.

Hypertension in pregnancy is also called Gestational Hypertensive Syndrome (GHS), a term used in this study to characterize this health condition, whose complications increase the incidence of morbidity and mortality and, together with infections and hemorrhages, are among the three main causes of maternal death in Brazil(4).

It is important to highlight risk factors that increase the likelihood of developing GHS, such as diabetes, kidney disease, obesity, multiple pregnancy, primiparity, age over 30 years, personal and/or family history of preeclampsia, chronic hypertension and ethnicity ${ }^{(5)}$.

Prenatal care is one of the fundamental actions for the prevention and treatment of GHS, positively impacting maternal and child health indicators. Thus, the main objective of prenatal and puerperal care is to provide medical attention for women from the beginning of pregnancy, ensuring a healthy end of pregnancy and childbirth and guaranteeing maternal and neonatal well-being(6).

Therefore, knowledge of the epidemiological profile, centered on the socioeconomic, demographic and obstetric characteristics of pregnant women with GHS, favors the planning of prenatal care, the early identification of the disease and the development of a therapeutic plan for the appropriate follow-up of high-risk pregnant women.

Nurses plays an important role in the care of hypertensive pregnant women, since they are capable of directing care to their clinical needs, thus improving the quality of care and, consequently, preventing complications caused by this problem. This study aims to describe the socioeconomic, demographic and obstetric profile of pregnant women with GHS and to verify correlations or associations between the variables.

\section{METHODS}

Descriptive, correlational and exploratory study, derived from the thesis entitled"Effect of an educational intervention for the prevention of complications of GHS: a randomized clinical trial", conducted in a maternal-fetal public tertiary care unit, located in a municipality in northeastern Brazil, reference in the care of high-risk pregnant women.

Pregnant women with medical diagnoses of GHS participated in the study. The age of the participants was not considered as a criterion. The criteria were: to be literate and have ability for verbal communication in the Portuguese language. Exclusion criteria were: gestational age greater than 33 weeks. This criterion was adopted because the development of the randomized clinical trial required two post-test applications after the intervention. The first post test was applied seven days after the intervention and the second was applied 30 days after. The limit considered for participants to go into labor was 38 weeks of pregnancy, to prevent sample loss. The sample consisted of 120 pregnant women.

Data were collected from November 2017 to April 2018, through interviews that used a questionnaire composed of objective questions developed by the researchers. Data collection was performed after the Informed Consent Form was signed.

The quantitative variables of the study were: age, educational level, family income, Body Mass Index (BMI), Systolic Blood Pressure (SBP), Diastolic Blood Pressure (DBP), number of prenatal consultations for the current pregnancy and previous pregnancies, childbirths, and abortions. The categorical variables of the study were: religion, skin color, employment, marital status, age group, educational level group, family income group, and type of hypertension diagnosis (chronic or gestational).

The family income, age and educational level groups were categorized using the median as cutoff point. BMI was categorized as: category I - overweight (25 - 29.99), obesity I (30 - 34.99); obesity II (35 - 39.99) and III (over 40).

Descriptive statistics were performed considering absolute (n) and relative (\%) frequency results for the categorical variables. Data for quantitative variables were analyzed considering the means, standard deviation, median, minimum and maximum values.

The nonparametric Mann-Whitney $\mathrm{U}$ test was used for analytical statistics of association between quantitative and categorical variables, according to an abnormal distribution 
assessed by the Shapiro-Wilk test. P-values less than or equal to 0.05 were considered significant.

The article was approved by the Research Ethics Committee (CAAE: 69789617.5.0000.5404) on October 2, 2017, in compliance with the ethical standards of Resolution $466 / 12^{(7)}$.

\section{RESULTS}

Among the 120 pregnant women with GHS, 73 had a diagnosis of chronic arterial hypertension (60.83\%) and 47 (39.17\%) of gestational hypertension. The socioeconomic, demographic and obstetric conditions of pregnant women with GHS are shown in Tables 1 and 2.

No significant differences were observed between BMI categories regarding SBP, DBP, educational level, family income and history of deliveries ( $p>0.05$ ). However, significant differences were found regarding the number of prenatal consultations during the current pregnancy $(p=0.026)$, previous pregnancies $(p=0.008)$, abortions $(p=0.017)$, and age $(p=0.002)$ (Table 3$)$.

In the comparisons between age groups, there was no statistical significance in relation to SBP, DBP, family income and the number of prenatal consultations of the current pregnancy ( $p>0.05)$. But significant differences were found regarding educational level $(p=0.043)$, history of pregnancies $(p=0.001)$, deliveries $(p=0.001)$, abortions $(p=0.004)$, and BMI $(p=0.026)$ (Table 3$)$.

When compared to the educational level categories, no significant results were identified regarding SBP, DBP, number of prenatal consultations of the current pregnancy, abortions, $\mathrm{BMI}$, and age ( $\mathrm{p}>0.05)$. Regarding the history of pregnancies $(p=0.010)$, childbirth $(p=0.001)$ and family income $(p=$ 0.007), significant differences were observed (Table 3 ).

By analyzing the Mann-Whitney $U$ test results, regarding family income categories, a significant difference was evidenced only in relation to educational level $(p=0.043)$. Regarding employment, a significant difference was observed in relation to the family income $(p=0.002)$. For comparisons regarding marital status, a significant difference regarding DBP was evidenced $(p=0.013)$.

Considering the type of gestational hypertension, it was observed that women with chronic hypertension were older $(p=0.0024)$, with a mean age of $32.47 \pm 6.69$ years, while the mean age of the others was of $28.57 \pm 6.74$ years, and they had a lower gestational age $(p=0.0219)$ and a higher number of abortions $(p=0.0140)$.

Table 1 - Sociodemographic profile of pregnant women with Gestational Hypertensive Syndrome $(n=120)$

\section{Variable}

n (\%)

Religion

Catholic

Evangelical

$35(29.2)$

Without Religion

Spiritist

$4(3.3)$

Others

$3(2.5)$

\section{Skin color}

\begin{tabular}{lr}
\hline Brown & $85(70.8)$ \\
\hline White & $19(15.8)$ \\
\hline Black & $13(10.8)$ \\
\hline Yellow & $3(2.6)$ \\
\hline
\end{tabular}

\section{Employment}

\begin{tabular}{ll}
\hline Yes & $72(60.0)$ \\
\hline No & $48(40.0)$ \\
\hline
\end{tabular}


Table 1 - Cont.

Variable

\section{Marital status}

Stable Union

Single

Age (years)

$18-31$

$32-46$

\section{Educational Level (years)}

$6-11$

$12-15$

\section{Family income (R\$)}

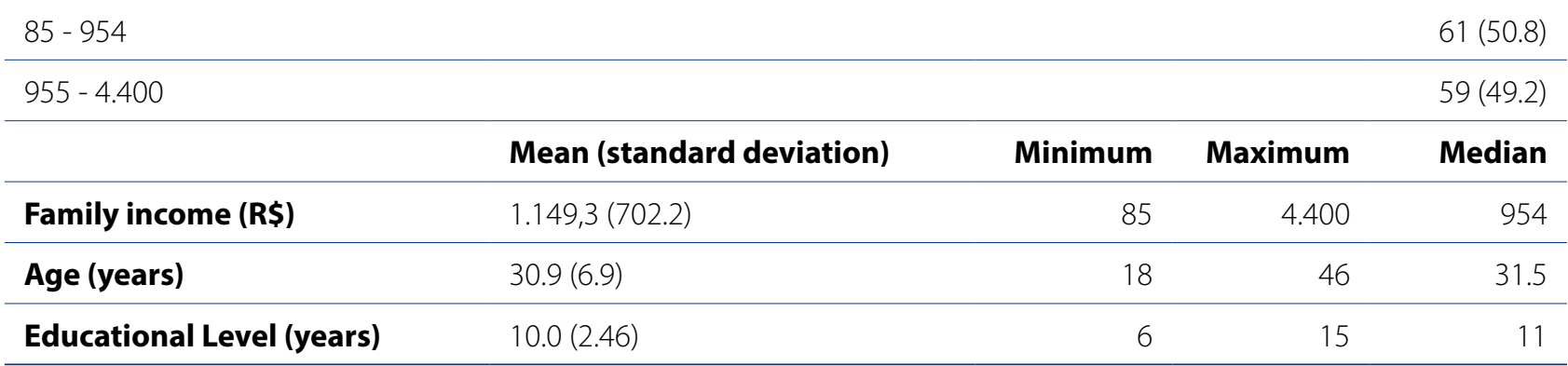

Source: Research data, 2019

Table 2 - Obstetric variables of pregnant women with Gestational Hypertensive Syndrome $(n=120)$

Variable

\section{Body Mass Index}

Obesity II and III $60(50.0)$

Overweight an Obesity I

\begin{tabular}{|c|c|c|c|c|}
\hline & Mean (standard deviation) & Minimum & Maximum & Median \\
\hline Systolic blood pressure (mmHg) & $129.86 \pm 16.43$ & 90 & 190 & 130 \\
\hline Diastolic Blood Pressure (mmHg) & $81.08 \pm 13.28$ & 30 & 120 & 80 \\
\hline Body Mass Index & $35.26 \pm 7.15$ & 20.7 & 66 & 34.41 \\
\hline $\begin{array}{l}\text { Number of prenatal } \\
\text { consultations for } \\
\text { current pregnancy }\end{array}$ & $5.29 \pm 2.70$ & 1 & 15 & 5 \\
\hline Gestations & $2.77 \pm 1.72$ & 1 & 8 & 2.5 \\
\hline Births & $1.18 \pm 1.39$ & 0 & 7 & 1 \\
\hline Abortions & $0.55 \pm 0.98$ & 0 & 6 & 0 \\
\hline
\end{tabular}

Source: Research data, 2019. 
Table 3 - Relations between the sociodemographic and obstetric profile with Body Mass Index, Age, and educational level of pregnant women with Gestational Hypertensive Syndrome $(n=120)$. Only significant results are presented.

\begin{tabular}{|c|c|c|c|}
\hline & \multicolumn{3}{|c|}{ Body Mass Index } \\
\hline & $\begin{array}{l}\text { Overweight and } \\
\text { obesity I }(n=60)\end{array}$ & $\begin{array}{c}\text { Obesity II } \\
\text { and III }(n=60)\end{array}$ & p-value ${ }^{*}$ \\
\hline $\begin{array}{l}\text { Number of prenatal consultations } \\
\text { during current pregnancy }\end{array}$ & 53.48 & 67.53 & 0.026 \\
\hline Gestations & 68.76 & 52.24 & 0.008 \\
\hline Abortions & 66.9 & 54.1 & 0.017 \\
\hline \multirow[t]{3}{*}{ Age groups } & 70.27 & 50.73 & 0.002 \\
\hline & \multicolumn{3}{|c|}{ Age } \\
\hline & 18 to $31(n=60)$ & 32 to $46(n=60)$ & p-value ${ }^{*}$ \\
\hline Educational Level (years) & 66.6 & 54.4 & 0.043 \\
\hline Gestations & 47.5 & 73.5 & 0.001 \\
\hline Births & 47.95 & 73.05 & 0.001 \\
\hline Abortions & 52.8 & 68.2 & 0.004 \\
\hline \multirow[t]{3}{*}{ Body Mass Index } & 67.56 & 53.44 & 0.026 \\
\hline & \multicolumn{3}{|c|}{ Educational level (years) } \\
\hline & 6 to $11(n=105)$ & 12 to $15(n=15)$ & p-value \\
\hline Gestations & 63.5 & 39.47 & 0.001 \\
\hline Births & 64.53 & 32.3 & 0.001 \\
\hline Family income & 57.3 & 82.9 & 0.007 \\
\hline
\end{tabular}

\section{DISCUSSION}

It is relevant to consider that pregnancy develops in a sociocultural context that determines its evolution and trajectory in healthcare. Considering this, it is also appropriate to point out aspects such as obstetric history and socioeconomic and demographic variables to know the risk factors that may interfere with maternal and fetal health assistance and so guide the care ${ }^{(8)}$.

In this study, 120 pregnant women diagnosed with GHS were interviewed. Most (59.2\%) declared themselves to be
Catholic, 70.8\% had brown skin color, 60\% were employed, $75.8 \%$ were in a stable union, $50 \%$ were aged 32 to 46 years, $87.5 \%$ had up to 11 years of schooling, and just over half (50.8\%) had a family income of up to $\mathrm{R} \$ 954.00$. These findings are in accordance with the profile of high-risk pregnant women evidenced in other national studies ${ }^{(8-9)}$.

The recommendations of the Ministry of Health for highrisk pregnancies ${ }^{(10)}$, as well as the principles of the Prenatal and Birth Humanization Program ${ }^{(11)}$ and the Cegonha Network ${ }^{(12)}$, suggests that pregnant women should have clinical and obstetric aspects evaluated often for early and appropriate 
identification of situations that may lead to complications to the development of pregnancies and, when found, refer the pregnant woman to high-risk prenatal care.

Regarding the obstetric profile, $50 \%$ of the women had a BMI of obesity II and III, SBP average of $129.86 \pm 16.43 \mathrm{mmHg}$ and DBP of $81.08 \pm 13.28 \mathrm{mmHg}$, had a mean of $5.29 \pm 2.70$ prenatal consultations for the current pregnancy and average history of $2.77 \pm 1.72$ pregnancies, $1.18 \pm 1.39$ deliveries and $0.55 \pm 0.98$ abortions. These findings converge with other researches, showing obstetric factors as risk factors for the development of GHS. It is important to note that all participants evaluated had a diagnosis of GHS.

Regarding marital status, occupation and educational levels, the study corroborates a research conducted with high-risk pregnant women, which showed $52 \%$ of married respondents and $64 \%$ with complete high school (11 years) ${ }^{(4)}$, but disagreed regarding occupation, as $60 \%$ of the interviewees were employed. Previous studies show a higher prevalence of housewives ${ }^{(13-14)}$.

Among these variables, the years of formal schooling deserve attention, since a lower time studying may represent a risk factor for one of the complications resulting from $\mathrm{GHS}^{(15)}$, as it is related to the lower access to information and the limited understanding of the importance of healthcare actions, especially regarding the prevention of early pregnancy and prospective history of multigestation, since significant differences in these variables were evidenced among those with lower educational levels.

The sample of this research can be characterized as vulnerable, due to the shorter time of schooling and family income, which makes it representative of the population attended by the public health service. It is noteworthy that unsatisfactory socioeconomic conditions may increase the risk of problems during pregnancy, since they are usually associated with greater stress and poor nutritional conditions $s^{(16)}$.

Regarding nutritional status during pregnancy, half the pregnant women reported being overweight, and there were significant differences, among those with lower BMI, with regards to the number of prenatal consultations of the current pregnancy, previous pregnancies, abortions, and age. Both maternal nutritional status and gestational weight gain have been the focus of several studies, due to the increasing prevalence of eating disorders, as well to the essential role of gestational outcomes. Maternal obesity influences maternal health, gestation time, and possible pre- and postpartum complications ${ }^{(16)}$.

Among the 120 pregnant women, half were older than 35 years of age, corroborating a previous study ${ }^{(13)}$. Women aged 35 years old or older are generally susceptible to adverse perinatal outcomes and maternal morbidity and mortality, since they are considered to be late pregnancies. Thus, studies show that due to ovarian senescence and the increased frequency of chronic diseases in women in this age group, as pregnancy is delayed, women are more likely to be susceptible to various risks ${ }^{(17-18)}$. It was noticed that, among the interviewees, the educational level and the history of pregnancies, births, abortions and BMI were different between younger and older women. The group of pregnant women with chronic hypertension was older than 30 years, which is in agreement with the literature ${ }^{(5)}$.

Longitudinal and population-based studies are needed to better define the risks associated with the occurrence of GHS in pregnant women assisted not only in the public service but also in the private sector. Identifying and controlling these factors as early as possible may reduce the impact of possible gestational complications.

Knowing the profile of pregnant women with GHS is important for professionals, especially those working in prenatal care, to direct actions for early diagnosis and prevention of major mother and newborn complications that GHS can cause during and after pregnancy.

Therefore, professionals must identify early the risk factors for GHS, enabling benefits for one of the most prominent public health sectors, which is currently targeted for maternal and neonate healthcare programs, thus reducing the mortality rates of mothers and children.

\section{CONCLUSIONS}

The group of pregnant women with GHS had a mean age of 30.9 years, social vulnerability, and overweight or obesity. Considering the type of arterial hypertension, pregnant women with chronic arterial hypertension are older and have a higher number of abortions.

The limitation of this study was its methodological design. The descriptive and exploratory design made it impossible to contribute to evidence GHS risk factors, limiting the study within the proposed descriptive setting. However, it is important to highlight that the results found can contribute to health services, since the information yielded can direct actions, especially during the prenatal consultation.

Thus, the results of the present study highlight the importance of knowing and analyzing the sociodemographic and obstetric data of the population in order to enable guided assistance in the promotion of healthy prenatal, delivery, and puerperium. 


\section{REFERENCES}

1. Ministério da Saúde (BR). Secretaria de Atenção à Saúde, Departamento de Atenção Básica. Atenção ao pré-natal de baixo risco. 1. ed. rev. Brasília: Ministério da Saúde; 2013 [cited 2019 Feb 23]. Available from: http://bvsms. saude.gov.br/bvs/publicacoes/atenca__pre_natal_baixo_risco.pdf

2. World Health Organization (CH). WHO recommendations for prevention and treatment of pre-eclampsia and eclampsia. Geneva: WHO; 2011 [cited 2019 Feb 23]. Available from: https://www.ncbi.nlm.nih.gov/books/NBK140555/

3. Henderson JT, Thompson JH, Burda BU, Cantor A, Beil T, Whitlock EP. Screening for preeclampsia: a systematic evidence review for the US Preventive Services Task Force. JAMA. 2017;317(16):1668-83. doi: https://doi.org/10.1001/ jama.2016.18315

4. Lima JP, Veras LLN, Pedrosa EKFS, Oliveira GSC, Guedes MVC. Socioeconomic and clinical profile of pregnant women with Gestational Hypertension Syndrome. Rev Rene. 2018;19:e3455. doi: https://doi.org/10.15253/21756783.2018193455

5. Nóbrega MF,Santos MTBR, Davim RMB, Oliveira LFM, AlvesESRC, RodriguesESRC. Profile of pregnantwomen with hypertensive syndrome in a public maternity. Rev Enferm UFPE on line. 2016 [cited 2019 Apr 10];10(5):1805-11. Available from: https://periodicos.ufpe.br/revistas/revistaenfermagem/article/view/13560 Amorim FCM, Neves ACN, Moreira FS, Oliveira ADS, Nery IS. Profile of pregnant women with pre-eclampsia. Rev enferm UFPE on line. 2017 [cited 2019 Apr 10];11(4):1574-83. Available from: https://periodicos.ufpe.br/revistas/ revistaenfermagem/article/view/15225

6. Ministério da Saúde (BR), Conselho Nacional de Saúde. Resolução nº 466, de 12 de dezembro de 2012. Diretrizes e normas regulamentadoras de pesquisas envolvendo seres humanos. Diário Oficial da União. 2013 jun 13;150(112 Seção 1):59-62.

7. Rodrigues ARM, Dantas SLC, Pereira AMM, Silveira MAM, Rodrigues DP. Highrisk pregnancy: analysis of health determinants. SANARE. 2017;16(supl 1):238. Portuguese. Available from: https://sanare.emnuvens.com.br/sanare/article/ viewFile/1135/620

8. Sbardelotto T, Pitilin EB, Schirmer J, Lentsck MH, Silva DTR, Tombini LHT. defining characteristics and factors associated with the occurrence of gestational hypertensive syndromes . Cogitare Enferm. 2018;23(2):e53699. doi: https:// doi.org/10.5380/ce.v23i2.53699

9. Ministério da Saúde (BR). Secretaria de Atenção à Saúde, Departamento de Ações Programáticas Estratégicas. Gestação de alto risco: manual técnic.. 5 a ed. Brasília: Ministério da Saúde; 2012 [cited 2019 Mar 15]. Available from: http://bvsms. saude.gov.br/bvs/publicacoes/manual_tecnico_gestaca__alto_risco.pdf
10. Ministério da Saúde (BR). Programa Humanização no Parto: humanização no pré-natal e nascimento: informações para gestores e técnicos. Brasília: Ministério da Saúde; 2002 [cited 2019 Mar 12]. Available from: http://bvsms. saude.gov.br/bvs/publicacoes/parto.pdf

11. Ministério da Saúde (BR). Portaria № 1.459, de 24 de junho de 2011. Institui, no âmbito do Sistema Único de Saúde - SUS - a Rede Cegonha. Brasília (DF): Ministério da Saúde; 2011.

12. Aldrighi JD, Ribeiro SS, Wall ML, Züge SS, Souza SRRK, Piler AA. Sociodemographic and obstetric profile of women in advanced maternal age. Rev Enferm UFSM. 2018;8(3):423-37. Portuguese. doi: https://doi. org/10.5902/2179769225922

13. Oliveira ACM, Graciliano NG. Hypertensive disorders of pregnancy and gestational diabetes mellitus in a public maternity hospital of a Northeastern Brazilian capital, 2013: prevalence and associated factors. Epidemiol Serv Saúde. 2015 [cited 2019 Apr 13];24(3):441-51. Available from: http:// www.scielo.br/scielo.php?pid=\$2237-96222015000300441\&script $=$ sci_ abstract\&tlng=en

14. Eze ED, Barasa A, Adams MD, Rabiu KM, Ezekiel I, Sulaiman SO, et al. Determination, knowledge and prevalence of pregnancy-induced hypertension/eclampsia among women of childbearing age at Same District Hospital in Tanzania. Int J Med Med Sci. 2018;10(2):19-26. doi: https://doi. org/10.5897/IJMMS2017.1343

15. Oliveira $A C$, Almeida LB, Lucca $A$, Nascimento V. Estudo da relação entre ganho de peso excessivo e desenvolvimento de diabetes mellitus e doença hipertensiva específica na gestação. J Health Sci Inst. 2016 [cited 2019 Mar 12];34(4):231-9. Available from: https://www.unip.br/presencial/ comunicacao/publicacoes/ics/edicoes/2016/04_out-dez/V34_n4_2016_ p231a239.pdf

16. Alves NCC, Feitosa KMA, Mendes MES, Caminha MFC. Complications in pregnancy in women aged 35 or older. Rev Gaúcha Enferm. 2017;38(4):201742. doi: https://doi.org/10.1590/1983-1447.2017.04.2017-0042

17. Bezerra ACL, Mesquita JS, Brito MCC, Teixeira FV. Desafios enfrentados por mulheres primigestas em idade avançada. Rev Bras Ciênc Saúde. 2015;19(2):163-8. doi: https://doi.org/10.4034/RBCS.2015.19.02.12

\section{Acknowledgments:}

This work received financial support from the Coordination for the Improvement of Higher Education Personnel - CAPES, through a PhD scholarship.

\section{- Corresponding author:}

Lia Maristela da Silva Jacob

lia_maristela@hotmail.com

\section{Associate editor: \\ Helga Geremias Gouveia}

Received: 05.27.2019

Approved: 12.06 .2019

\section{Editor-in-chief:}

Maria da Graça Oliveira Crossetti 